Article

\title{
Farnesoid X Receptor Activation Enhances Transforming Growth Factor $\beta$-Induced Epithelial-Mesenchymal Transition in Hepatocellular Carcinoma Cells
}

\author{
Masahiko Kainuma ${ }^{1,2}$, Ichiro Takada ${ }^{1, *}$, Makoto Makishima ${ }^{1, *}$ and Keiji Sano 2 (iD) \\ 1 Division of Biochemistry, Department of Biomedical Sciences, Nihon University School of Medicine, \\ 30-1 Oyaguchi-kamicho, Itabashi-ku, Tokyo 173-8610, Japan; kainumamasahiko23@yahoo.co.jp \\ 2 Department of Surgery, Teikyo University School of Medicine, 2-11-1 Kaga, Itabashi-ku, \\ Tokyo 173-8605, Japan; k2sano-tky@umin.ac.jp \\ * Correspondences: takada.ichiro@nihon-u.ac.jp (I.T.); makishima.makoto@nihon-u.ac.jp (M.M.); \\ Tel.: +81-3-3972-8111 (M.M. \& I.T.)
}

Received: 26 May 2018; Accepted: 26 June 2018; Published: 28 June 2018

\begin{abstract}
Farnesoid X receptor (FXR) is a receptor for bile acids and plays an important role in the regulation of bile acid metabolism in the liver. Although FXR has been shown to affect hepatocarcinogenesis through both direct and indirect mechanisms, potential roles of FXR in epithelial-mesenchymal transition (EMT) in hepatocellular carcinoma (HCC) remain unclear. We examined the effect of several FXR ligands on EMT-related morphological changes in HCC cell lines, such as HuH-7 and Hep3B cells. FXR agonists (chenodeoxycholic acid, GW4064, and obeticholic acid) — but not an antagonist (guggulsterone)—induced actin polymerization and expression of $\mathrm{N}$-cadherin and phosphorylated focal adhesion kinase, although they were less effective than transforming growth factor $\beta$ (TGF- $\beta$ ). FXR agonist treatment enhanced TGF- $\beta$-induced EMT morphologic changes and FXR antagonist inhibited the effect of TGF- $\beta$. Thus, FXR activation enhances EMT in HCC and FXR antagonists may be EMT-suppressing drug candidates.
\end{abstract}

Keywords: farnesoid $X$ receptor; bile acid; hepatocellular carcinoma; epithelial-mesenchymal transition; guggulsterone; transforming growth factor $\beta$; $\mathrm{N}$-cadherin; focal adhesion kinase

\section{Introduction}

Hepatocellular carcinoma (HCC) is the most common primary cancer of the liver and is the third leading cause of cancer-related death in the world [1]. HCC can be cured by surgical resection, which is available only for patients with early-stage disease. High mortality in HCC patients is due to invasion, intra- and extrahepatic metastasis, and postsurgical recurrence. Epithelial-mesenchymal transition (EMT) plays a role in the early steps of invasion and metastasis in many cancers, including HCC [2]. Therapies targeting EMT could prolong survival of HCC patients.

Farnesoid X receptor (FXR) is a nuclear receptor activated by bile acids and plays an essential role in the regulation of bile acid metabolism by suppressing the synthesis and import of bile acids in hepatocytes and stimulating their biliary excretion [3-6]. FXR also regulates glucose and lipid metabolism. FXR activation protects hepatocytes against bile acid-induced cytotoxicity, inhibits hepatic lipogenesis, and increases insulin sensitivity [7]. Indeed, the FXR ligand obeticholic acid is being studied in clinical trials for nonalcoholic steatohepatitis and primary biliary cholangitis $[8,9]$.

In addition to metabolic regulation, FXR is involved in hepatic regeneration and carcinogenesis. FXR activation accelerates liver regeneration and induces forkhead box M1 transcription factor, a cell 
cycle regulator [10,11]. FXR also promotes liver regeneration through induction of fibroblast growth factor 15 in the intestine [12]. On the other hand, spontaneous hepatocarcinogenesis is induced in FXR-null mice [13,14]. Interestingly, hepatocarcinogenesis in FXR-null mice is repressed by intestinal FXR transgene expression [15]. Dysregulation of bile acid metabolism in the intestine of FXR-null mice is suggested to influence hepatocarcinogenesis. Thus, FXR influences hepatocarcinogenesis through both direct and indirect mechanisms. In this study, we report that FXR activation enhances EMT of HCC cells.

\section{Results}

\subsection{FXR Agonist Induces EMT Phenotypes in HCC Cells}

To examine whether FXR regulates EMT in HCC cells, we treated HuH-7 cells with FXR ligand for $48 \mathrm{~h}$ and assessed morphological changes. Chenodeoxycholic acid (CDCA) is a potent natural FXR agonist [3] and GW4064 and obeticholic acid (OCA) are synthetic agonists [16,17], while guggulsterone (GS) is an FXR antagonist that has been identified as the cholesterol-lowering agent in the extract of the guggul tree [18]. Similar to transforming growth factor $\beta$ (TGF- $\beta$ ), which is a strong EMT inducer for HCC cells [2], the FXR agonists GW4064, CDCA, and OCA, but not the antagonist GS, enhanced actin polymerization in HuH-7 cells (Figure 1A). Increased actin polymerization was also observed in Hep3B cells treated with CDCA, GW4064, OCA, and TGF- $\beta$, but not in GS-treated cells (Figure 1B).

A $\mathrm{HuH}-7$

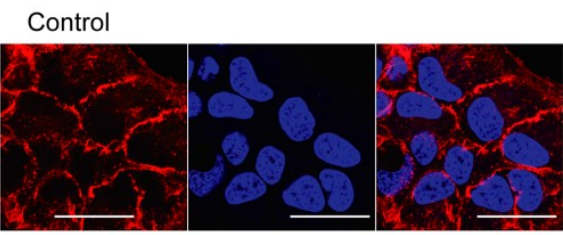

GS

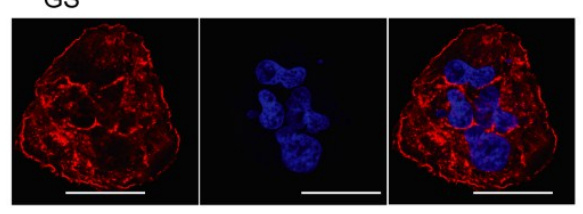

OCA

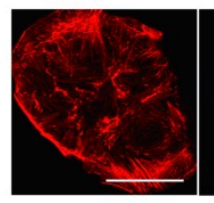

Phalloidin (Actin)

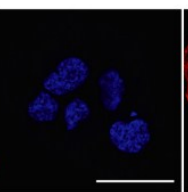

DAPI

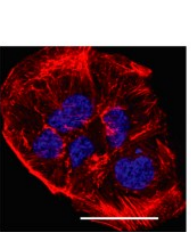

Merged

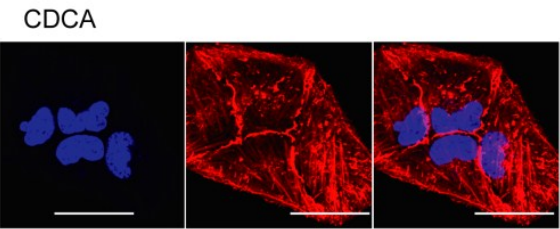

GW4064

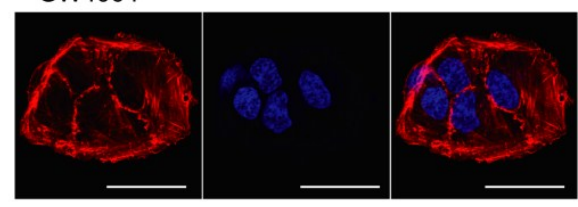

TGF- $\beta$

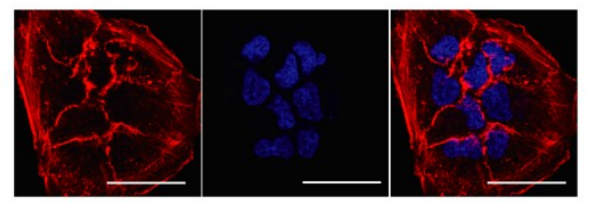

Phalloidin (Actin)

DAPI

Merged

B Hep3B

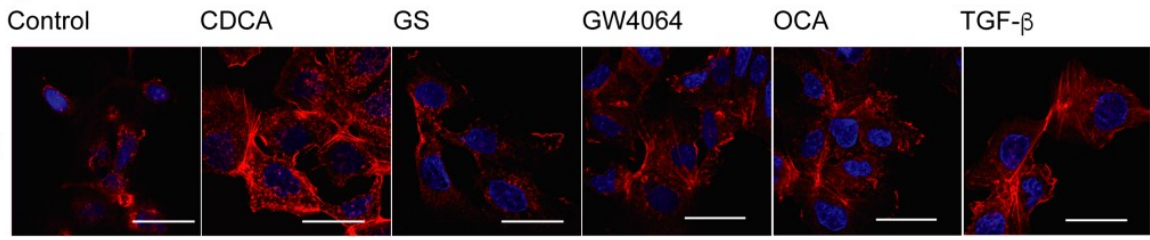

Figure 1. Farnesoid $\mathrm{X}$ receptor (FXR) activation induces actin polymerization in HuH-7 cells (A) and Hep3B cells (B). Cells were treated with vehicle control (Control), $100 \mu \mathrm{M}$ chenodeoxycholic acid (CDCA), $32 \mu \mathrm{M}$ guggulsterone (GS), $10 \mu \mathrm{M}$ GW4064, $10 \mu \mathrm{M}$ obeticholic acid (OCA), or $10 \mathrm{ng} / \mathrm{mL}$ transforming growth factor $\beta$ (TGF- $\beta$ ) for $48 \mathrm{~h}$ and stained with rhodamine phalloidin (red) to detect actin polymerization and with DAPI (blue) to show nuclei. Scale bar, $50 \mu \mathrm{m}$. 
We also examined the expression of another EMT marker, N-cadherin, in HuH-7 cells [2]. In agreement with a previous report [19], TGF- $\beta$ treatment induced $N$-cadherin expression (Figure 2). Immunostaining also showed increased N-cadherin expression in cells treated with GW4064, CDCA, and OCA, but not with GS. In a Western blot analysis, increased N-cadherin protein levels were also observed in cells treated with GW4064 (Figure A1).

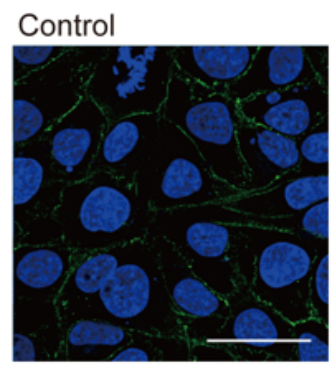

CDCA

GS

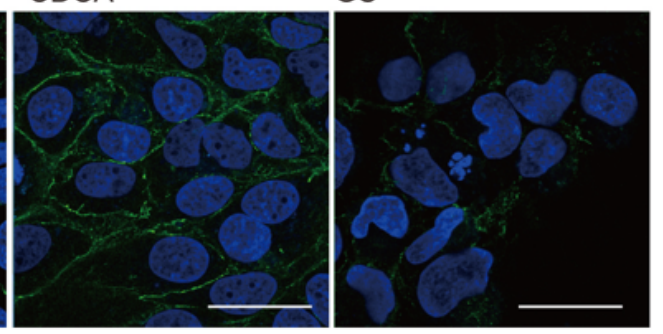

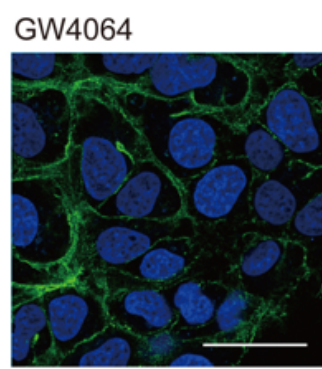

$\mathrm{N}$-cadherin/DAP
OCA

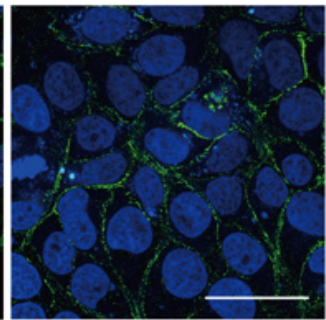

$\mathrm{N}$-cadherin/DAPI
TGF- $\beta$

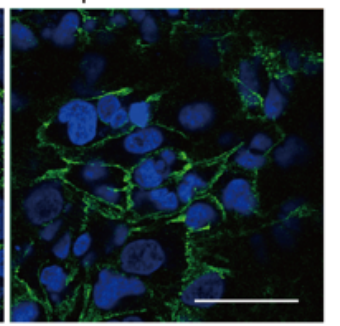

$\mathrm{N}$-cadherin/DAPI

Figure 2. FXR activation induces $\mathrm{N}$-cadherin expression in $\mathrm{HuH}-7$ cells. Cells were treated with vehicle control (Cont), $100 \mu \mathrm{M}$ CDCA, $32 \mu \mathrm{M}$ GS, $10 \mu \mathrm{M}$ GW4064, $10 \mu \mathrm{M}$ OCA, or $10 \mathrm{ng} / \mathrm{mL}$ TGF- $\beta$ for 48 hours and stained for N-cadherin (green) and DAPI (blue). Scale bar, $50 \mu \mathrm{m}$.

Next, we examined mRNA expression of EMT-related genes. Although TGF- $\beta$ increased mRNA expression of $C D H 2$, which encodes N-cadherin, GW4064 and OCA had no effect and CDCA and GS decreased mRNA levels in HuH-7 cells (Figure 3). GW4064 and OCA increased SNAI1 mRNA levels but CDCA, GS, and TGF- $\beta$ did not. Expression of $C D H 1$, a gene encoding E-cadherin, was not changed in any cell conditions. Expression of the FXR target gene NR0B2, which encodes the small heterodimer partner [20], was increased by treatment with CDCA, GW4064, and OCA, while it was slightly decreased in cells treated with GS and TGF- $\beta$. These findings indicate that FXR agonists induce EMT phenotypes in HCC cells in a slightly different manner to TGF- $\beta$.

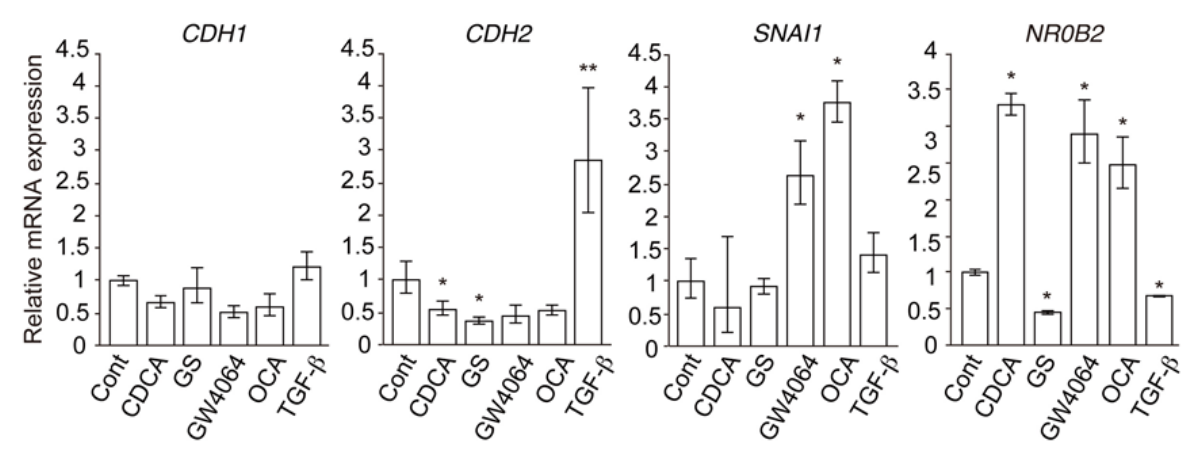

Figure 3. Expression of epithelial-mesenchymal transition (EMT)-related genes and the FXR target gene NROB2 in HuH-7 cells. Cells were treated with vehicle control (Cont), $100 \mu \mathrm{M}$ CDCA, $32 \mu \mathrm{M}$ GS, $10 \mu \mathrm{M}$ GW4064, $10 \mu \mathrm{M}$ OCA, or $10 \mathrm{ng} / \mathrm{mL}$ TGF- $\beta$ for $48 \mathrm{~h}$. ${ }^{*} p<0.05$; ${ }^{* *} p<0.01$ versus Cont. 


\subsection{Combined Effect of FXR Ligand and TGF- $\beta$ in EMT of HCC Cells}

Treatment of HuH-7 cells with TGF- $\beta$ or GW4064 induced expression of phosphorylated focal adhesion kinase (FAK), a marker correlated with invasion activity of HCC [21] (Figure 4A). Phosphorylated FAK co-localized with polymerized actin and expression patterns of these proteins were different in HuH-7 cells treated with TGF- $\beta$ and those with GW4064. TGF- $\beta$ induced mesenchymal morphological changes more effectively than GW4064. GS did not induce these findings. Western blotting showed that GW4064 and TGF- $\beta$ increased phosphorylated FAK expression (Figure 4B). TGF- $\beta$ plus GW4064 did not further increase its expression. Interestingly, GS suppressed the EMT phenotype induced by TGF- $\beta$ (Figure 4 A,B).

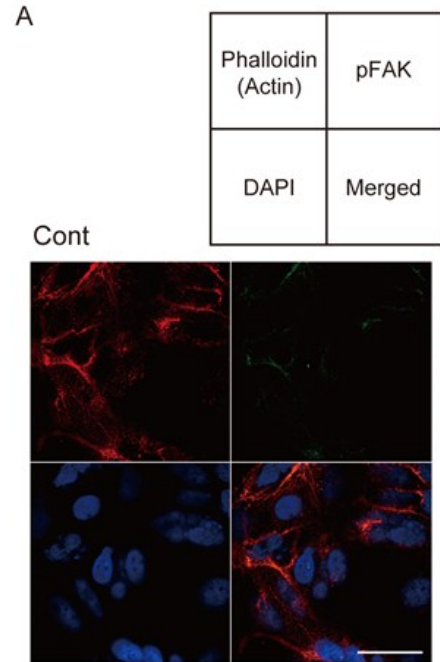

TGF- $\beta$

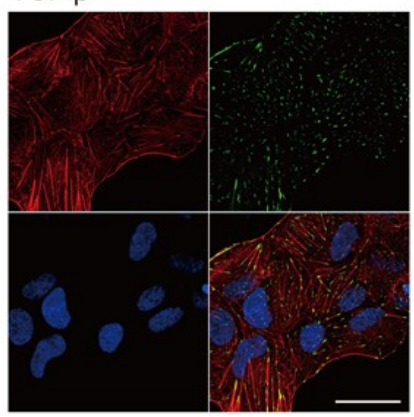

TGF- $\beta+$ GW4064
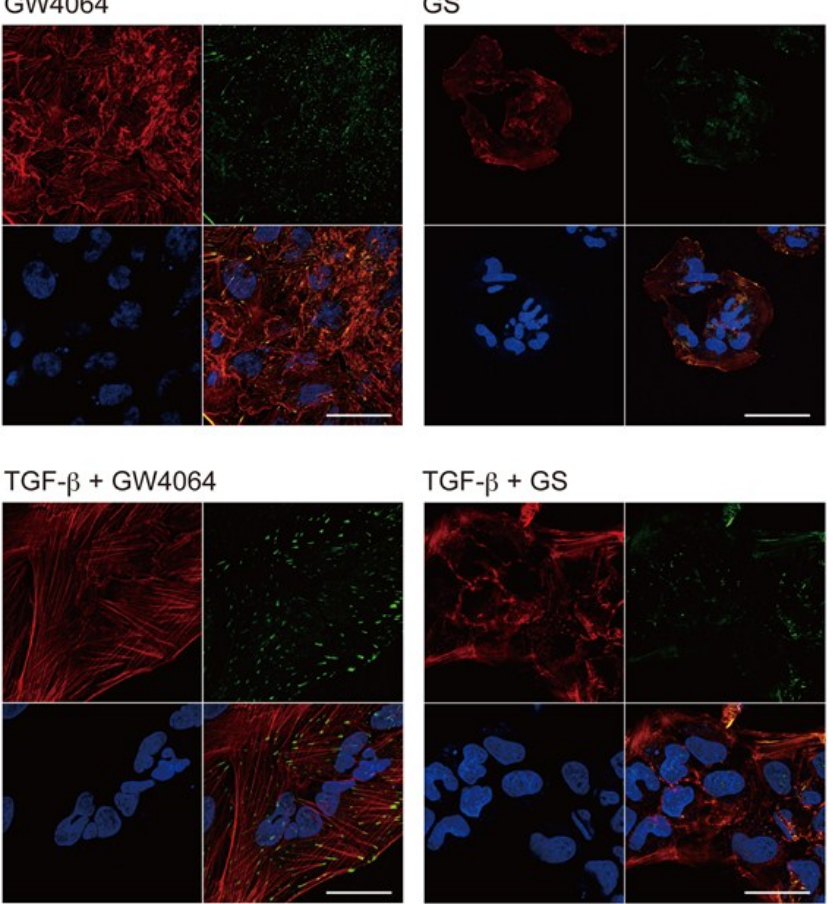

TGF- $\beta$ + GS

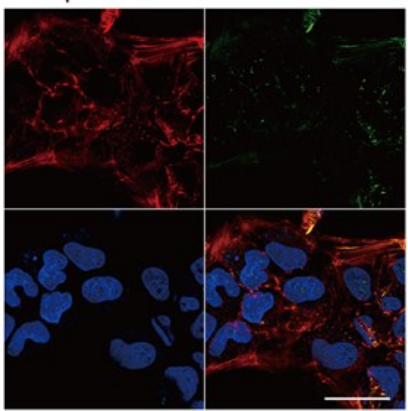

B

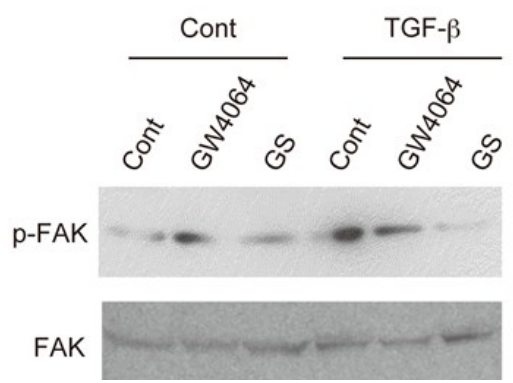

Figure 4. Combined effects of TGF- $\beta$ and GW4064 or GS on phosphorylated FAK (p-FAK) expression in HuH-7 cells. (A) Actin polymerization (red) and phosphorylated FAK (p-FAK; green); DAPI (blue); and (B) Western blotting for p-FAK and total FAK. Cells were treated with vehicle control (Cont), 10 $\mu \mathrm{M}$ GW4064, or $32 \mu \mathrm{M}$ GS in the absence or presence of $10 \mathrm{ng} / \mathrm{mL}$ TGF- $\beta$ for $48 \mathrm{~h}$. Scale bar, $50 \mu \mathrm{m}$. 
The addition of GW4064 increased and that of GS suppressed TGF- $\beta$-induced N-cadherin expression in HuH-7 cells (Figure 5A). In contrast to the immunostaining findings, GW4064 did not change and GS suppressed $\mathrm{CDH} 2$ mRNA expression in TGF- $\beta$-treated cells (Figure 5B).

A

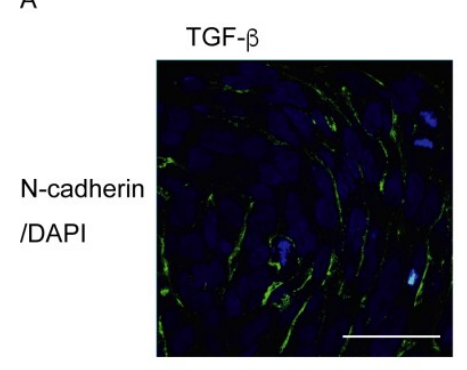

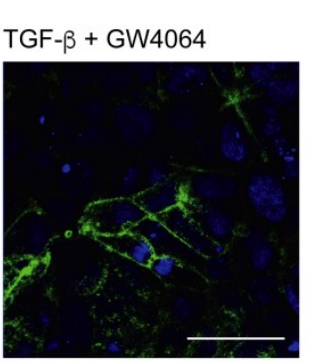

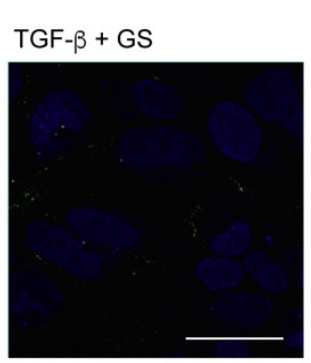

B

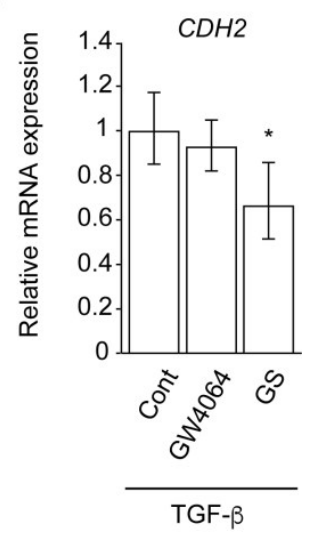

Figure 5. Combined effects of TGF- $\beta$ and GW4064 or GS on N-cadherin expression in HuH-7 cells. (A) N-cadherin protein expression (green); and (B) $\mathrm{CDH} 2 \mathrm{mRNA}$ expression. Cells were treated with vehicle control (Cont), $10 \mu \mathrm{M}$ GW4064, or $32 \mu \mathrm{M}$ GS in the absence or presence of $10 \mathrm{ng} / \mathrm{mL}$ TGF- $\beta$ for 48 h. Scale bar, $50 \mu \mathrm{m} .{ }^{*} p<0.05$ versus Cont.

\section{Discussion}

In this study, we found that FXR agonism promotes and FXR antagonism suppresses EMT phenotypes in HCC cells. In contrast, antitumor effects of FXR agonists have been reported. FXR agonist treatment inhibits proliferation of SK-GI-18 cells, which are FXR-overexpressing SK-Hep-1 cells, and suppresses tumor growth and metastasis in an orthotopic xenograft model with these cells in nude mice [22]. Recently, OCA was reported to suppress proliferation, migration, and invasion of HepG2 cells and HuH-7 cells [23]. Our preliminary experiments showed higher concentrations of CDCA, GS, GW4064, and OCA inhibited cell proliferation. To avoid their toxic effects, we chose non-toxic concentrations of these compounds (100 $\mu \mathrm{M}$ CDCA, $32 \mu \mathrm{M}$ GS, $10 \mu \mathrm{M}$ GW4064, and $10 \mu \mathrm{M}$ OCA). Effective concentrations of these compounds are dependent on cell culture conditions, such as cell density, medium, serum, and duration. The discrepancy between our results and others may be due to the concentrations of ligands or activation status of FXR. Super-physiological FXR activation may suppress proliferation and migration/invasion of HCC. Our results suggest that physiological FXR activation promotes EMT phenotypes. Hepatocarcinogenesis is enhanced in FXR-null mice [13,14] and FXR expression is decreased in human HCC samples [24]. These findings support the tumor-suppressing role of FXR. On the other hand, there is a significant association between nuclear FXR expression and Ki-67 labeling in human HCC samples [25]. FXR activation suppresses inflammatory responses [6]. FXR may act as a tumor suppressor at the initiation or early stage of HCC through the regulation of bile acid metabolism and inflammation and play a different role in the late stage of HCC as an EMT enhancer.

Our results showed that FXR agonists were less effective than TGF- $\beta$ in EMT morphology induction (Figures 1, 2 and 4). TGF- $\beta$, but not FXR agonists, effectively induced $C D H 2$ expression (Figure 3). On the other hand, GW4064 and OCA, but not TGF- $\beta$, increased SNAI1 expression (Figure 3). GS treatment decreased $C D H 2$ expression induced by TGF- $\beta$ (Figure 5). These findings suggest that FXR agonists enhance EMT phenotypes in a manner different from TGF- $\beta$. We could not find an FXR-responsive element in the CDH1, $C D H 2$, and SNAI1 promoters. Similar to the EMT-suppressing effect in our results (Figures 4 and 5), GS decreases motility and invasion of pancreatic cancer cells [26]. GW4064 enhances and GS inhibits EMT changes in TGF- $\beta$-treated human bronchial epithelial cells [27], and bile acids, including CDCA, also induce EMT in human lung alveolar cells [28]. 
Interestingly, lithocholic acid, which is a weak FXR agonist [3], stimulates TGF- $\beta$ release from lung fibroblasts [28]. FXR may enhance EMT by modulating TGF- $\beta$ signaling. There was a discrepancy between protein and mRNA expression of N-cadherin (Figures 2 and 3). FXR agonists stimulate insulin secretion in mouse pancreatic $\beta$ cells via an FXR-mediated non-genomic action [29]. It remains unclear whether the effect of FXR ligand on EMT is mediated by a genomic or non-genomic action. Further studies are needed to determine the underlying mechanism of FXR action on EMT.

FXR activation inhibits hepatic inflammation [6]. Recently, OCA has been studied in clinical trials for nonalcoholic steatohepatitis and primary biliary cholangitis [8,9]. On the other hand, disturbance in bile acid homeostasis, including accumulation of FXR-activating bile acids, is associated with nonalcoholic fatty liver and nonalcoholic steatohepatitis [30]. Increasing levels of deoxycholic acid, which is another weak FXR agonist [3], promote hepatocellular carcinogenesis [31]. OCA enhanced TGF- $\beta$-induced EMT phenotypes (Figures 4 and 5). Although FXR plays a role in protection against bile acid toxicity and pathogenesis by regulating bile acid metabolism [6], OCA and other FXR agonists should be used with caution for patients with HCC. The FXR antagonist GS exhibits cholesterol-lowering activity [18]. Therefore, GS or synthetic FXR antagonists [32] may be able to prolong survival of late-stage HCC patients.

\section{Materials and Methods}

\subsection{Cell Culture}

Human HCC HuH-7 cells and Hep3G cells were obtained from the American Type Culture Collection and cultured in DMEM high glucose (Wako Pure Chemical Industries, Osaka, Japan) supplemented with $10 \%$ fetal bovine serum, $50 \mathrm{U} / \mathrm{L}$ penicillin, and $50 \mu \mathrm{g} / \mathrm{L}$ streptomycin. Cell were treated with vehicle control, $100 \mu \mathrm{M}$ CDCA (Wako Pure Chemical Industries), $32 \mu \mathrm{M}$ GS (Enzo Life Science, Farmingdale, NY, USA), $10 \mu$ M GW4064 (ChemScene, Monmouth Junction, NJ, USA), $10 \mu \mathrm{M}$ OCA (AdipoGen Life Sciences, San Diego, CA, USA) and/or 10 ng/mL TGF- $\beta$ (PeproTech, Rocky Hill, NJ, USA) for $48 \mathrm{~h}$.

\subsection{Immunolostaing}

Cells were fixed in $4 \%$ paraformaldehyde and blocked in 5\% skim milk/phosphate buffer saline with $0.1 \%$ Tween-20 (PBST). After washing in PBST, cell samples were incubated with rabbit anti-FAK(p397) antibody (Abcam, Cambridge, UK) or mouse anti-N-cadherin antibody (BD Biosciences, San Jose, CA, USA) in 5\% skim milk/PBST, washed with PBST twice, and incubated with Akexa488-conjugated anti-rabbit IgG antibody or Alexa546-conjugated anti-mouse IgG antibody (Thermo Fisher Scientific, Waltham, MA, USA). Cell specimens were also stained with rhodamine phalloidin (Cytoskelton, Inc., Denver, CO, USA). Mounted cell specimens were analyzed with a confocal microscope (ZSM710; Carl Zeiss, Jena, Germany).

\subsection{Western Blotting}

Proteins were subjected to sodium dodecyl sulfate-polyacrylamide gel electrophoresis and transferred to nitrocellulose membranes. Membranes were blocked with PBST with $2.5 \%$ skim milk, incubated with anti-FAK(p397) antibody (Abcam), anti-FAK antibody (BD Biosciences), anti-N-cadherin antibody (BD Biosciences), or anti- $\beta$-actin antibody (Sigma-Aldrich, St. Louis, MO, USA), and then with horseradish peroxidase-coupled secondary antibody (Agilent, Santa Clara, CA, USA), and visualized with the ECL Western Blotting Detection Reagents (GE Healthcare, Chalfont St. Giles, UK).

\section{4. mRNA Expression}

Total RNA was extracted using TRIZOL (Thermo Fisher Scientific) and cDNA was synthesized using PrimeScript Reverse Transcriptase (Takara Bio, Otsu, Japan). Quantitative polymerase chain 
reaction was performed using ABI PRISM7000 (Thermo Fisher Scientific) with Light Cycler SYBR Green I Master Mix (Takara Bio), and quantification was performed as reported previously [33]. Used primer sequences were: $C D H 2,5^{\prime}$-TGG AGA CAT TGG GGA CTT CA-3' and 5'-ATT AAG GGA GCT CAA GGA CC-3'; CDH1, 5' - GAA GGT GAC AGA GCC TCT GGA TAG-3' and 5'-CTG GAA GAG CAC CTT CCA TGA-3'; SNAI1, 5'-AAG ATG CAC ATC CGA AGC CA-3' and 5'-CTT GAC ATC TGA GTG GGT CT-3'; NR0B2, 5'-AAT ATG CCT GCC TGA AAG GGA-3' and 5'- GAT AGG GCG AAA GAA GAG GTC C-3'; GAPDH, 5'-ACT TCG CTC AGA CAC CAT GG-3' and 5'-GTA GTT GAG GTC AAT GAA GGG-3'. The mRNA levels were adjusted to those of GAPDH, a gene encoding glyceraldehyde-3-phosphate dehydrogenase.

\subsection{Statistical Analysis}

Data are presented as the mean \pm S.D. We performed one-way ANOVA followed by Tukey's multiple comparisons to assess significant differences.

Author Contributions: M.K. and I.T. performed experiments, analyzed the data, and wrote the manuscript. M.M. supervised experiments and wrote the manuscript. K.S. supervised the study.

Funding: This work was supported by JSPS KAKENHI Grant Number JP 15J10224 (to M.K.) and Children's Cancer Association of Japan (to M.K.). M.K. was a Research Fellow of the Japan Society for the Promotion of Science (JSPS).

Acknowledgments: The authors thank staffs of the Collaborative Research Resources, School of Medicine, Keio University for technical assistance, members of Makishima lab for technical assistance and helpful comments and Andrew I. Shulman for editorial assistance.

Conflicts of Interest: The authors declare no conflict of interest.

\section{Abbreviations}

HCC Hepatocellular carcinoma

EMT Epithelial-mesenchymal transition

FXR Farnesoid $X$ receptor

CDCA Chenodeoxycholic acid

OCA Obeticholic acid

GS Guggulsterone

TGF- $\beta$ Transforming growth factor $\beta$

FAK Focal adhesion kinase

PBST Phosphate buffer saline with Tween-20

\section{Appendix A}

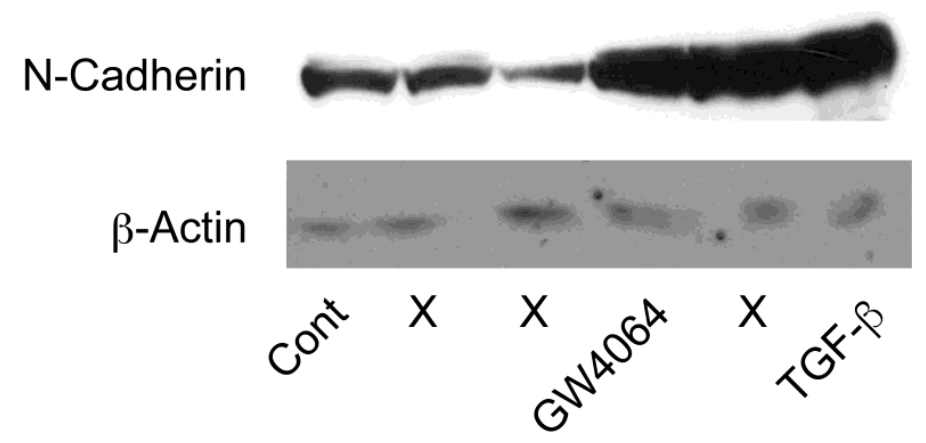

Figure A1. Western blotting for N-cadherin. Cells were treated with vehicle control (Cont), $10 \mu \mathrm{M}$ GW4064, or $10 \mathrm{ng} / \mathrm{mL}$ TGF- $\beta$ for $48 \mathrm{~h}$. Lanes indicated with an $\mathrm{X}$ were not subjected for evaluation. 


\section{References}

1. Jia, W.; Xie, G.; Jia, W. Bile acid-microbiota crosstalk in gastrointestinal inflammation and carcinogenesis. Nat. Rev. Gastroenterol. Hepatol. 2017, 15, 111-128. [CrossRef] [PubMed]

2. Giannelli, G.; Koudelkova, P.; Dituri, F.; Mikulits, W. Role of epithelial to mesenchymal transition in hepatocellular carcinoma. J. Hepatol. 2016, 65, 798-808. [CrossRef] [PubMed]

3. Makishima, M.; Okamoto, A.Y.; Repa, J.J.; Tu, H.; Learned, R.M.; Luk, A.; Hull, M.V.; Lustig, K.D.; Mangelsdorf, D.J.; Shan, B. Identification of a nuclear receptor for bile acids. Science 1999, 284, 1362-1365. [CrossRef] [PubMed]

4. Parks, D.J.; Blanchard, S.G.; Bledsoe, R.K.; Chandra, G.; Consler, T.G.; Kliewer, S.A.; Stimmel, J.B.; Willson, T.M.; Zavacki, A.M.; Moore, D.D.; et al. Bile acids: Natural ligands for an orphan nuclear receptor. Science 1999, 284, 1365-1368. [CrossRef] [PubMed]

5. Wang, H.; Chen, J.; Hollister, K.; Sowers, L.C.; Forman, B.M. Endogenous bile acids are ligands for the nuclear receptor FXR/BAR. Mol. Cell 1999, 3, 543-553. [CrossRef]

6. Li, T.; Chiang, J.Y. Bile acid signaling in metabolic disease and drug therapy. Pharmacol. Rev. 2014, 66, 948-983. [CrossRef] [PubMed]

7. De Magalhaes Filho, C.D.; Downes, M.; Evans, R.M. Farnesoid X receptor an emerging target to combat obesity. Dig. Dis. 2017, 35, 185-190. [CrossRef] [PubMed]

8. Neuschwander-Tetri, B.A.; Loomba, R.; Sanyal, A.J.; Lavine, J.E.; Van Natta, M.L.; Abdelmalek, M.F.; Chalasani, N.; Dasarathy, S.; Diehl, A.M.; Hameed, B.; et al. Farnesoid X nuclear receptor ligand obeticholic acid for non-cirrhotic, non-alcoholic steatohepatitis (FLINT): A multicentre, randomised, placebo-controlled trial. Lancet 2015, 385, 956-965. [CrossRef]

9. Nevens, F.; Andreone, P.; Mazzella, G.; Strasser, S.I.; Bowlus, C.; Invernizzi, P.; Drenth, J.P.; Pockros, P.J.; Regula, J.; Beuers, U.; et al. A placebo-controlled trial of obeticholic acid in primary biliary cholangitis. N. Engl. J. Med. 2016, 375, 631-643. [CrossRef] [PubMed]

10. Huang, W.; Ma, K.; Zhang, J.; Qatanani, M.; Cuvillier, J.; Liu, J.; Dong, B.; Huang, X.; Moore, D.D. Nuclear receptor-dependent bile acid signaling is required for normal liver regeneration. Science 2006, 312, 233-236. [CrossRef] [PubMed]

11. Chen, W.D.; Wang, Y.D.; Zhang, L.; Shiah, S.; Wang, M.; Yang, F.; Yu, D.; Forman, B.M.; Huang, W. Farnesoid X receptor alleviates age-related proliferation defects in regenerating mouse livers by activating forkhead box m1b transcription. Hepatology 2010, 51, 953-962. [CrossRef] [PubMed]

12. Zhang, L.; Wang, Y.D.; Chen, W.D.; Wang, X.; Lou, G.; Liu, N.; Lin, M.; Forman, B.M.; Huang, W. Promotion of liver regeneration/repair by farnesoid $x$ receptor in both liver and intestine in mice. Hepatology 2012, 56, 2336-2343. [CrossRef] [PubMed]

13. Yang, F.; Huang, X.; Yi, T.; Yen, Y.; Moore, D.D.; Huang, W. Spontaneous development of liver tumors in the absence of the bile acid receptor farnesoid $X$ receptor. Cancer Res. 2007, 67, 863-867. [CrossRef] [PubMed]

14. Kim, I.; Morimura, K.; Shah, Y.; Yang, Q.; Ward, J.M.; Gonzalez, F.J. Spontaneous hepatocarcinogenesis in farnesoid X receptor-null mice. Carcinogenesis 2007, 28, 940-946. [CrossRef] [PubMed]

15. Degirolamo, C.; Modica, S.; Vacca, M.; Di Tullio, G.; Morgano, A.; D’Orazio, A.; Kannisto, K.; Parini, P.; Moschetta, A. Prevention of spontaneous hepatocarcinogenesis in farnesoid $\mathrm{X}$ receptor-null mice by intestinal-specific farnesoid $x$ receptor reactivation. Hepatology 2015, 61, 161-170. [CrossRef] [PubMed]

16. Maloney, P.R.; Parks, D.J.; Haffner, C.D.; Fivush, A.M.; Chandra, G.; Plunket, K.D.; Creech, K.L.; Moore, L.B.; Wilson, J.G.; Lewis, M.C.; et al. Identification of a chemical tool for the orphan nuclear receptor FXR. J. Med. Chem. 2000, 43, 2971-2974. [CrossRef] [PubMed]

17. Pellicciari, R.; Fiorucci, S.; Camaioni, E.; Clerici, C.; Costantino, G.; Maloney, P.R.; Morelli, A.; Parks, D.J.; Willson, T.M. $6 \alpha$-Ethyl-chenodeoxycholic acid (6-ECDCA), a potent and selective fxr agonist endowed with anticholestatic activity. J. Med. Chem. 2002, 45, 3569-3572. [CrossRef] [PubMed]

18. Urizar, N.L.; Liverman, A.B.; Dodds, D.T.; Silva, F.V.; Ordentlich, P.; Yan, Y.; Gonzalez, F.J.; Heyman, R.A.; Mangelsdorf, D.J.; Moore, D.D. A natural product that lowers cholesterol as an antagonist ligand for FXR. Science 2002, 296, 1703-1706. [CrossRef] [PubMed] 
19. Nagahara, T.; Shiraha, H.; Sawahara, H.; Uchida, D.; Takeuchi, Y.; Iwamuro, M.; Kataoka, J.; Horiguchi, S.; Kuwaki, T.; Onishi, H.; et al. Hepatic stellate cells promote upregulation of epithelial cell adhesion molecule and epithelial-mesenchymal transition in hepatic cancer cells. Oncol. Rep. 2015, 34, 1169-1177. [CrossRef] [PubMed]

20. Lu, T.T.; Makishima, M.; Repa, J.J.; Schoonjans, K.; Kerr, T.A.; Auwerx, J.; Mangelsdorf, D.J. Molecular basis for feedback regulation of bile acid synthesis by nuclear receptors. Mol. Cell 2000, 6, 507-515. [CrossRef]

21. Chen, J.S.; Huang, X.H.; Wang, Q.; Chen, X.L.; Fu, X.H.; Tan, H.X.; Zhang, L.J.; Li, W.; Bi, J. Fak is involved in invasion and metastasis of hepatocellular carcinoma. Clin. Exp. Metastasis 2010, 27, 71-82. [CrossRef] [PubMed]

22. Deuschle, U.; Schüler, J.; Schulz, A.; Schlüter, T.; Kinzel, O.; Abel, U.; Kremoser, C. FXR controls the tumor suppressor NDRG2 and FXR agonists reduce liver tumor growth and metastasis in an orthotopic mouse xenograft model. PLoS ONE 2012, 7, e43044. [CrossRef] [PubMed]

23. Attia, Y.M.; Tawfiq, R.A.; Ali, A.A.; Elmazar, M.M. The FXR agonist, obeticholic acid, suppresses hcc proliferation \& metastasis: Role of IL-6/STAT3 signalling pathway. Sci. Rep. 2017, 7, 12502. [PubMed]

24. Su, H.; Ma, C.; Liu, J.; Li, N.; Gao, M.; Huang, A.; Wang, X.; Huang, W.; Huang, X. Downregulation of nuclear receptor FXR is associated with multiple malignant clinicopathological characteristics in human hepatocellular carcinoma. Am. J. Physiol. Gastrointest. Liver Physiol. 2012, 303, G1245-G1253. [CrossRef] [PubMed]

25. Kumagai, A.; Fukushima, J.; Takikawa, H.; Fukuda, T.; Fukusato, T. Enhanced expression of farnesoid X receptor in human hepatocellular carcinoma. Hepatol. Res. 2013, 43, 959-969. [CrossRef] [PubMed]

26. Macha, M.A.; Rachagani, S.; Gupta, S.; Pai, P.; Ponnusamy, M.P.; Batra, S.K.; Jain, M. Guggulsterone decreases proliferation and metastatic behavior of pancreatic cancer cells by modulating JAK/STAT and Src/FAK signaling. Cancer Lett. 2013, 341, 166-177. [CrossRef] [PubMed]

27. Chen, B.; You, W.J.; Xue, S.; Qin, H.; Zhao, X.J.; Zhang, M.; Liu, X.Q.; Zhu, S.Y.; Jiang, H.D. Overexpression of farnesoid $X$ receptor in small airways contributes to epithelial to mesenchymal transition and COX-2 expression in chronic obstructive pulmonary disease. J. Thorac. Dis. 2016, 8, 3063-3074. [CrossRef] [PubMed]

28. Chen, B.; Cai, H.R.; Xue, S.; You, W.J.; Liu, B.; Jiang, H.D. Bile acids induce activation of alveolar epithelial cells and lung fibroblasts through farnesoid $X$ receptor-dependent and independent pathways. Respirology 2016, 21, 1075-1080. [CrossRef] [PubMed]

29. Düfer, M.; Hörth, K.; Wagner, R.; Schittenhelm, B.; Prowald, S.; Wagner, T.F.J.; Oberwinkler, J.; Lukowski, R.; Gonzalez, F.J.; Krippeit-Drews, P.; et al. Bile acids acutely stimulate insulin secretion of mouse $\beta$-cells via farnesoid $x$ receptor activation and katp channel inhibition. Diabetes 2012, 61, 1479-1489. [CrossRef] [PubMed]

30. Chow, M.D.; Lee, Y.-H.; Guo, G.L. The role of bile acids in nonalcoholic fatty liver disease and nonalcoholic steatohepatitis. Mol. Aspects Med. 2017, 56, 34-44. [CrossRef] [PubMed]

31. Yoshimoto, S.; Loo, T.M.; Atarashi, K.; Kanda, H.; Sato, S.; Oyadomari, S.; Iwakura, Y.; Oshima, K.; Morita, H.; Hattori, M.; et al. Obesity-induced gut microbial metabolite promotes liver cancer through senescence secretome. Nature 2013, 499, 97-101. [CrossRef] [PubMed]

32. Kainuma, M.; Makishima, M.; Hashimoto, Y.; Miyachi, H. Design, synthesis, and evaluation of non-steroidal farnesoid X receptor (FXR) antagonist. Bioorg. Med. Chem. 2007, 15, 2587-2600. [CrossRef] [PubMed]

33. Takada, I.; Tsuchiya, M.; Yanaka, K.; Hidano, S.; Takahashi, S.; Kobayashi, T.; Ogawa, H.; Nakagawa, S.; Makishima, M. Ess2 bridges transcriptional regulators and spliceosomal complexes via distinct interacting domains. Biochem. Biophys. Res. Commun. 2018, 497, 597-604. [CrossRef] [PubMed]

(C) 2018 by the authors. Licensee MDPI, Basel, Switzerland. This article is an open access article distributed under the terms and conditions of the Creative Commons Attribution (CC BY) license (http:// creativecommons.org/licenses/by/4.0/). 